\title{
Inhibitory Role of the Mud Crab Short Neuropeptide $F$ in Vitellogenesis and Oocyte Maturation via Autocrine/Paracrine Signaling
}

\author{
Chenchang Bao ${ }^{1}$, Yanan Yang ${ }^{1}$, Huiyang Huang ${ }^{1}$ and Haihui Ye ${ }^{1,2 *}$ \\ ${ }^{1}$ College of Ocean and Earth Sciences, Xiamen University, Xiamen, China, ${ }^{2}$ Fujian Collaborative Innovation Center for \\ Exploitation and Utilization of Marine Biological Resources, Xiamen, China
}

Neuropeptides, in addition to their classical role in the nervous system, act on intraovarian factors to regulate reproductive functions in vertebrates. However, this function of neuropeptides has not been characterized in crustaceans. Short neuropeptide F (sNPF), a highly conserved invertebrate neuropeptide, has been reported to be involved in feeding, metabolism, and in differentiation processes including reproduction. Although sNPF and its receptor (sNPFR) have been detected in the ovary in different species, ovarian colocalization of sNPF/sNPFR has not been investigated. In this study, we

OPEN ACCESS

Edited by:

Takayoshi Ubuka,

Monash University Malaysia, Malaysia

Reviewed by:

Honoo Satake,

Suntory Foundation for Life Sciences,

Japan

Tsuyoshi Ohira,

Kanagawa University, Japan

${ }^{*}$ Correspondence:

Haihui Ye

haihuiye@xmu.edu.cn

Specialty section

This article was submitted to Experimental Endocrinology,

a section of the journal

Frontiers in Endocrinology

Received: 17 April 2018

Accepted: 25 June 2018

Published: 13 July 2018

Citation:

Bao C, Yang $Y$, Huang $\mathrm{H}$ and $\mathrm{Ye} H$ (2018) Inhibitory Role of the Mud Crab Short Neuropeptide F in Vitellogenesis and Oocyte Maturation via Autocrine/Paracrine Signaling.

Front. Endocrinol. 9:390 doi: 10.3389/fendo.2018.00390 identified Scylla paramamosain (mud crab) sNPF (Sp-sNPF) as an endogenous ligand for the S. paramamosain orphan G protein-coupled receptor NPY2R in mammalian cell line HEK293T. We designated this receptor as Sp-SNPFR. RNA in situ hybridization in pre-vitellogenic ovary and reverse transcription-PCR on isolated denuded oocytes and follicle layers showed that Sp-sNPF was exclusively localized to the follicle cells, whereas $S p$-SNPFR was detected in both follicle cells and oocytes. We also found that Sp-sNPF partly suppressed spontaneous maturation of denuded oocytes and caused intracellular cAMP accumulation and $\mathrm{Ca}^{2+}$ mobilization. Moreover, injection of synthetic Sp-sNPF peptides inhibited the expression of vitellogenin and vitellogenin receptor genes in vivo. These combined results suggest for the first time that Sp-sNPF may have inhibitory functions in vitellogenesis and oocyte maturation possibly via the autocrine/paracrine pathway.

\section{Keywords: short neuropeptide F, ovary, oocyte maturation, vitellogenesis, crustacean}

\section{INTRODUCTION}

Neuropeptides are widespread in the nervous system of animals (1). Neuropeptides are secreted from neural cells and act as neuromodulators or neurotransmitters in the nervous system (2). Furthermore, neuropeptides are secreted from neuroendocrine cells, transported through blood to peripheral organs, and function as neurohormones (3). They also play a pivotal role in regulating reproduction (4). One such example is that of gonadotropin-releasing hormone $(\mathrm{GnRH})$, a key decapeptide hormone involved in the regulation of reproduction which is secreted by the hypothalamus and transported via the hypophysial portal system to stimulate the production of luteinizing hormone ( $\mathrm{LH}$ ) and follicle-stimulating hormone (FSH), which further act on the ovary $(5,6)$. In addition to its involvement in this classical hypothalamic-pituitary-gonadal (HPG) 
reproduction axis in vertebrates, $\mathrm{GnRH}$ also plays a role as a neuroendocrine factor by directly binding to its receptor (GnRHR) in the ovary $(7,8)$. Mostly, neuropeptides are released by the nervous system and regulate reproduction directly or indirectly $(8,9)$. However, neuropeptides can also act as intraovarian regulatory factors. Intraovarian $\mathrm{GnRH} / \mathrm{GnRHR}$ system has been suggested to play an autocrine/paracrine role in gonadal steroidogenesis, cell proliferation, and apoptosis (8, 1013). In addition to GnRH/GnRHR, two key upstream regulation neuropeptide systems, gonadotrophin-inhibitory hormone $(\mathrm{GnIH}) / \mathrm{GnIH}$ receptor (GnIHR) and kisspeptin/kisspeptin receptor, in the vertebrate reproduction axis also exist in ovary (14-23). The regulation of intraovarian neuropeptides has been well studied in vertebrates $(7,8,18,24,25)$. However, a detailed knowledge about the intraovarian neuropeptides acting on ovary in invertebrates has not been reported.

Short neuropeptide F (sNPF), a homolog of vertebrate neuropeptide Y (NPY), is a C-terminally conserved neuropeptide in invertebrates. sNPF belongs to FMRFa-like peptides (FLPs) with the RFamide conserved motif (26) and has been widely studied in insects, especially in Drosophila (27). The first sNPF isolated from the midgut of American cockroach, Periplaneta americana, was postulated to play a role in digestion (28). Studies have mainly focused on the role of $s$ PPF in regulation of feeding and metabolism (29-34). However, a role for sNPF in reproduction has also been identified. For instance LedNPF-1, sNPF peptide from Leptinotarsa decemlineata (Colorado potato beetle) and Scg-NPF, a Locusta migratoria sNPF peptide, were shown to accelerate egg development in L. migratoria (34-37). However, their regulatory role in signaling is not known. Drosophila sNPF and its receptor (sNPFR) have been considered as upstream regulators of insulin signaling pathway (30). In Drosophila, sNPF and sNPFR1 proteins were detected in the larval brain where sNPFR1 was localized to the brain insulin producing cells (IPCs) and sNPFnergic neurons were found adjacent to these IPCs $(30,38)$. SNPF peptides stimulate insulin-like peptides (ILPs) synthesis in IPCs and affect insulin signaling (30). In insects, insulin signaling pathway regulates developmental and differentiation functions such as reproduction $(39,40)$. Juvenile hormone $(\mathrm{JH})$ and 20-hydroxyecdysone (20E) were found to act as the insect gonadotropic hormones and to be regulated by insulin signaling by a complex physiological regulatory network $(39,40)$. sNPF peptides can directly regulate the production of $\mathrm{JH}$. In the silkworm, Bombyx mori, sNPF peptides localize to the corpora cardiaca and inhibit JH biosynthesis in the corpora allata $(41,42)$. Moreover, sNPF was speculated as a neurohormone directly functioning on the ovary of red imported fire ant, Solenopsis invicta Buren as the S. invicta SNPF receptor (Si-sNPFR) protein was detected in oocytes by immunolocalization (43). These findings suggest that sNPF may serve as neuro-regulator in reproduction. Whether or not $\mathrm{sNPF}$ directly stimulates ovary is not known.

Recently, with the rapid development of methodologies, such as next-generation sequencing and mass spectrometry, many sNPF peptides have been identified in various crustacean species including the mud crab (Scylla paramamosain) (44-50).
However, the reproductive function of $\mathrm{sNPF}$ in crustaceans is not known. S. paramamosain sNPF ( $S p$-sNPF) transcript was identified to encode a 126 amino acids (aa) precursor peptide with a 25 aa signal peptide followed by three mature peptides, each 9-12 aa in length and each containing a XPXRLRFamide (X represent variable residues) conserved motif (44). Interestingly, in our previous study, we found that $S p$ sNPF transcript was highly expressed in the ovary in addition to the nervous system (44). We hypothesized that sNPF may act as intraovarian regulatory factor similar to vertebrate neuropeptides. In this study, we investigated the potential intraovarian autocrine/paracrine role of $S p$-sNPF by receptor identification, ligand-receptor localization, signal transduction, and by biological relevance.

\section{MATERIALS AND METHODS}

\section{Animals}

Crabs were purchased in the eighth market in Xiamen, Fujian Province, China. According to histological characteristics (51) and gonadosomatic index (GSI) (52), ovarian development was classified into five stages: undeveloped stage (stage I, GSI $=0.57$ \pm 0.47 ), pre-vitellogenic stage (stage II, GSI $=2.19 \pm 0.21$ ), early vitellogenic stage (stage III, GSI $=3.68 \pm 0.20$ ), late vitellogenic stage (stage IV, GSI $=7.81 \pm 0.94$ ), and mature stage (stage $\mathrm{V}$, GSI $=10.49 \pm 0.49$ ). Anesthesia on ice was administered before dissections. The study was approved by Xiamen University animal care committee.

\section{Molecular Cloning and Plasmid Construction}

Total RNA from the crab ovary was isolated with the Trizol Reagent (Invitrogen) according to the manufacturer's instructions. The cDNA was synthetized using the RevertAid First Strand cDNA Synthesis Kit (Thermo) as per manufacturer's instructions. To clone the entire coding region of $S p$-sNPFR gene, primers (Table 1) were designed based on the sequence in the transcriptome databases of brain (SRA accession: SRP068003) and muscle (SRA accession: SRP111448) from S. paramamosain. PCR product was sequenced prior to inserting into the HindIII and BamHI sites of the pEGFP-N1 vector. The construct was sequenced to validate the sequence and orientation.

\section{Cell Culture and Transient Transfection}

Human embryonic kidney cell lines (HEK293T) were maintained in high glucose DMEM (Hyclone) supplemented with $10 \%$ fetal bovine serum (Gibco), $100 \mathrm{U} / \mathrm{mL}$ penicillin and $100 \mu \mathrm{g} / \mathrm{mL}$ streptomycin (Hyclone) at $37^{\circ} \mathrm{C}$ in a humidified incubator (Thermo) containing $5 \% \mathrm{CO}_{2}$. Cells were seeded overnight in 6-well plates and transiently co-transfected with $1 \mu \mathrm{g}$ of the $S p$-sNPFR/pEGFP-N1 plasmid, $0.8 \mu \mathrm{g}$ of the reporter gene pCRE-luc, and $0.4 \mu \mathrm{g}$ of internal control gene pRL-TK using $5 \mu \mathrm{L}$ Lipofectamine 2000 (Invitrogen) reagent following the manufacturer's protocols. Empty pEGFP-N1 plasmid was used for mock transfection. 
TABLE 1 | Primers used for plasmid construction, real-time PCR and in situ hybridization probe preparation.

\begin{tabular}{|c|c|}
\hline Primers and Probes & Sequences \\
\hline \multicolumn{2}{|c|}{ PRIMERS FOR SP-SNPFR-EXPRESSING PLASMID CONSTRUCTION } \\
\hline Sp-sNPFR-ORF-F & 5'-CCCAAGCTTGCCACCATGATGGGCTCGAGCACCTTAC-3' \\
\hline Sp-sNPFR-ORF-R & 5' -CGCGGATCCCGCACATACTCGGACGCCTCGC-3' \\
\hline \multicolumn{2}{|c|}{ PRIMERS FOR IN SITU HYBRIDIZATION PROBE PREPARATION } \\
\hline Sp-sNPF probe-F & 5'-ATGGGCGTGAACGGCGT-3’ \\
\hline Sp-sNPF probe-R & 5'-TTACTGCTCCTGGCTGACCATGT-3' \\
\hline Sp-sNPFR probe-F & 5'-GAGGCGTCCGAGTATGTGTGAA-3' \\
\hline Sp-sNPFR probe-R & 5'-CATITGATGTCGTAAAGCTGAAGTG-3' \\
\hline \multicolumn{2}{|l|}{ PRIMERS FOR REAL-TIME PCR } \\
\hline Sp-sNPF real-time- $F^{\star}$ & 5'-GGTGACTCCGATTTAATGCTT-3' \\
\hline Sp-sNPF real-time- $R^{\star}$ & 5'-TGGCTTCCACTGCCGCTA-3' \\
\hline Sp-sNPFR real-time-F & 5'-CAAGTGCTAACCGCTGTAAAATG-3' \\
\hline Sp-sNPFR real-time- $R$ & 5'-CGTCCAGGATGGTGTITAGTGA-3' \\
\hline$S p-V g$ quantitative real-time- $F^{\star \star}$ & 5'-GAGTGATGATGGAGGTGTCCTG-3' \\
\hline$S p-V g$ quantitative real-time- $R^{\star \star}$ & 5'-GACCTTGAGCGATTCTGGTGACGA-3' \\
\hline Sp-VgR quantitative real-time- $F^{\star \star \star}$ & 5'-TTCTATACCAGGCCACTACC-3' \\
\hline$S p-V g R$ quantitative real-time- $R^{\star \star \star}$ & $5^{\prime}-\Pi \Pi T$ САCTCCAAGCACACTC-3' \\
\hline$\beta$-actin- $F^{\star \star}$ & 5'-GAGCGAGAAATCGTTCGTGAC-3' \\
\hline$\beta$-actin- $R^{\star \star}$ & 5'-GGAAGGAAGGCTGGAAGAGAG-3' \\
\hline
\end{tabular}

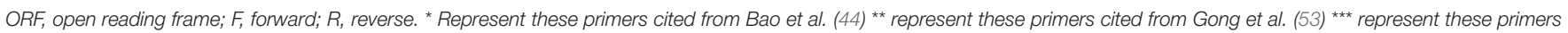
cited from Shu et al. (54).

\section{Confocal Microscopy}

For detection of sNPFR expression on the cell surface, HEK293T transiently transfected with $S p$-sNPFR/pEGFP-N1 plasmid for $24 \mathrm{~h}$ were stained with the cell membrane probe DiI (Beyotime) at $37^{\circ} \mathrm{C}$ for $10 \mathrm{~min}$ and fixed with $4 \%$ paraformaldehyde (PFA) for $15 \mathrm{~min}$. Cells were further incubated with a nuclear dye DAPI (Invitrogen) for $10 \mathrm{~min}$. Stained cells were mounted in $50 \%$ glycerol and imaged using a two-photon laser confocal fluorescence microscopy (LSM 780 NLO, Zeiss).

\section{Activation of Signaling}

HEK293T transiently co-transfected with $S p$-sNPFR/pEGFP-N1 and dual-luciferase reporter system vectors were grown to $90 \%$ confluency in a 24-well plate. Cells were first treated with synthetic $S p$-sNPF peptide mixture and the mixture containing 9 synthetic FLPs (GL Biochem, Table 2) at $1 \mu \mathrm{M}$ each. Further, various concentrations of individual peptides were used to record dose-dependent curves. After incubation for $6 \mathrm{~h}$, ligand-induced changes in luciferase activity were measured by GloMax ${ }^{\circledR} 20 / 20$ Luminometer (Promega) with Dual-Luciferase ${ }^{\circledR}$ Reporter Assay System Kit (Promega).

\section{In Situ Hybridization}

Crab ovaries in a pre-vitellogenic stage were dissected, fixed in $4 \%$ PFA, and prepared for in situ hybridization as described (53). Primers, listed in Table 1, spanning 381 and 250 bp nucleotides of $S p-s N P F$ and $S p$-sNPFR cDNA, respectively, were used for the preparation digoxigenin-labeled cRNA riboprobes using a DIGRNA Labeling Kit (Roche). Hybridization was performed at $57^{\circ} \mathrm{C}$ for $16 \mathrm{~h}$ according to the manufacturer's instructions.
TABLE 2 | Sequences of synthetic peptides for binding tests.

\begin{tabular}{llll}
\hline Peptides & Sequence & Peptides & Sequence \\
\hline Mixture-1 & & Mixture-2 & \\
Sp-sNPF1 & APPSMRLRF-NH2 & Sp-FLRFamide-1 & GYSKNYLRF-NH2 \\
Sp-sNPF2 & SMPTLRLRF-NH2 & Sp-FLRFamide-4/9 & DRNFLRF-NH2 \\
Sp-sNPF3 & KDARTPALRLRF- & Sp-FLRFamide-5 & SGHRNYLRF- \\
& NH2 & & NH2 \\
& & Sp-FLRFamide-8 & GYNRSFLRF-NH2 \\
& & Sp-NPF156-66 & YFAIAGRPRF- \\
& & & NH2 \\
& & Sp-NPF259-69 & IYSHMTRPRF- \\
& & & NH2 \\
& & Sp-FMRFamide & FMRF-NH2 \\
& & Sp-sulfakinin-1 & EFDDY(SO3H) \\
& & & GHMRF-NH2 \\
& & Sp-myosuppressin & pQDLDHVFRF- \\
& & & NH2
\end{tabular}

All peptides were purified by HPLC and the purity is over 95\%. -NH2 indicates C-terminal amidation. $p Q$ indicates $\mathrm{N}$-terminal pyroglutamylation. $Y_{(\mathrm{SO})}$ in $)$ indicates Tyrosine sulfate.

\section{Isolation and Incubation of Crab Ovary}

Ovaries (late vitellogenic stage) with fully grown (FG) oocytes were removed from female crabs and placed in $10 \mathrm{~cm}$ culture dish containing calcium-free crab saline $(440 \mathrm{mM}$ $\mathrm{NaCl}, 11.3 \mathrm{mM} \mathrm{KCl}, 26 \mathrm{mM} \mathrm{MgCl} 2,10 \mathrm{mM}$ Hepes, $10 \mathrm{mM}$ Glucose, pH 7.4 adjusted with $\mathrm{NaOH}$ ) (55). The follicle layers were carefully separated with fine forceps under 
stereoscope (Leica). To determine the expression of $S p$ $s N P F$ and $S p$-sNPFR gene, total RNA from intact ovary, denuded oocytes, and follicle layers were extracted with the Trizol Reagent (Invitrogen). cDNA was synthesized using TransScript II One-Step gDNA Removal and cDNA Synthesis SuperMix kit (TransGen Biotech) according to the manufacturer's protocols. The cDNA templates were used for PCR amplification using $S p-s N P F$ and $S p-s N P F R$ primers (Table 1). PCR products were analyzed by $1.5 \%$ agarose gel electrophoresis.

\section{Intracellular Calcium Measurement}

The denuded oocytes were washed thrice after they were separated from the ovaries with FG oocytes and were loaded with $1 \mu \mathrm{M}$ Fluo-4 AM (Molecular Probes) for $40 \mathrm{~min}$ in $25^{\circ} \mathrm{C}$. Oocytes were washed thrice, resuspended in calcium-free crab saline, and incubated for $30 \mathrm{~min}$ at $25^{\circ} \mathrm{C}$. Calcium flux was measured in oocytes stimulated with $S p$-sNPF peptides using excitation at 486 and emission at $526 \mathrm{~nm}$ in a fluorescence spectrometer (Infinite 200Pro, Tecan).

\section{Effect of Sp-sNPFs on Oocyte Maturation}

To obtain spontaneously matured oocytes, ovaries with the oocytes in germinal vesicle (GV) stage were placed in a glass dish with crab serum (the status of GV stage oocytes was maintained better in crab serum than that in crab saline, data not shown). After the follicle layers were removed, the denuded oocytes were isolated from ovary and incubated in crab serum containing $5 \mu \mathrm{M} S p$-sNPF peptides. The observation of oocyte germinal vesicle breakdown (GVBD) was carried out as described (56). The GVBD was counted in intact ovary as well as in the denuded oocytes following incubation with in Sp-sNPF peptides for 0, 5 , 15,30 , and $60 \mathrm{~min}$.

\section{Measurement of the Accumulation of CAMP}

The measurement of cAMP accumulation and the calculation of GVBD rate were performed at the same time. Oocytes were lysed and the concentration of cAMP was determined using a competitive binding technique based on enzymelinked immunosorbent assay (ELISA) (cAMP EIA kit, Cayman) according to the manufacturer's protocols.

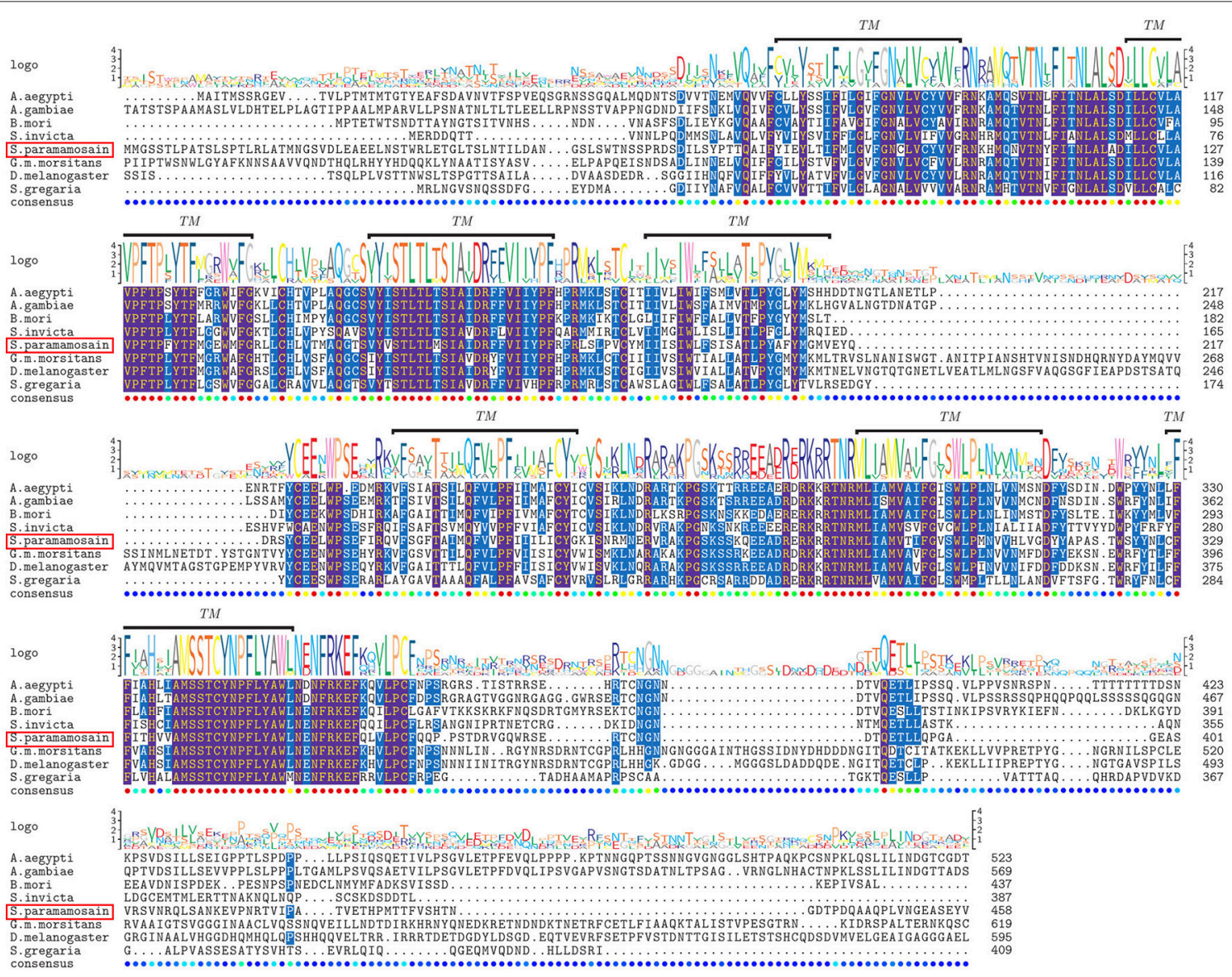

FIGURE 1 | Comparative sequence alignment of SNPF receptors in different animals. Protein sequence alignment of sNPF receptors for S. paramamosain with Aedes aegypti, Anopheles gambiae, Bombyx mori, Solenopsis invicta, Glossina morsitans morsitans, Drosophila melanogaster and Schistocerca gregaria. The transmembrane helices are indicated by TM. Sequence logo is shown above alignments. 


\section{In Vivo Effect of Sp-sNPF Peptides on $S p-V g$ and $S p-V g R$ Expression}

Female crabs in pre-vitellogenic stage (weighing 45-56 g) were reared in the laboratory and were fed a shrimp diet. The initial control crabs were sacrificed on first day of the injection assay. Ten microliter of $1 \mathrm{mM} S p$-sNPF peptides (final concentration in hemolymph about $5 \mu \mathrm{M}$ ) were injected into the arthrodial membrane at the base of last walking leg every 2 days while concurrent control crabs received the same volume of carrier.

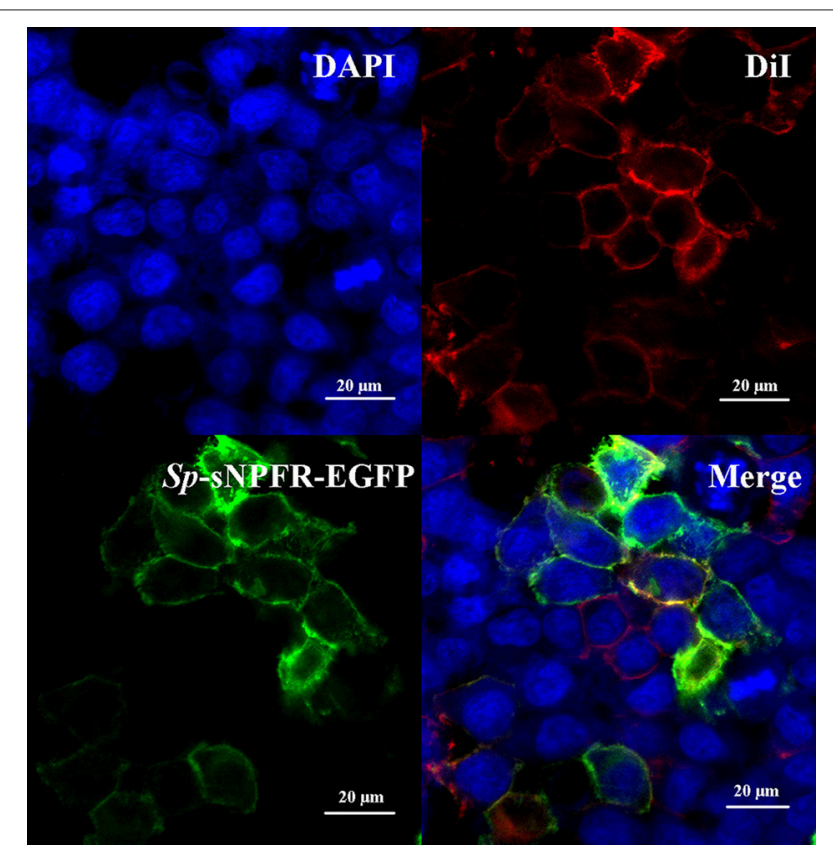

FIGURE 2 | Expression of Sp-sNPFR in HEK293T. HEK293T were transiently co-transfected with Sp-sNPFR/pEGFP-N1, pCRE-luc and pRL-TK. Cells expressing $S p$-sNPFR-EGFP fusion protein were stained with a nuclei probe (DAPI) and a membrane plasma probe (Dil).
After 10 days, crabs were dissected and RNA extracted. cDNA was synthesized from hepatopancreas and ovaries and used in quantitative real-time PCR (qRT-PCR) to detect the expression level of vitellogenin $(S p-V g)$ and vitellogenin receptor $(S p-V g R)$. The qRT-PCR was performed in the 7500 Fast Real-Time PCR system (Applied Biosystems) with SYBR Premix Ex Taq (TaKaRa) as following protocol: $95^{\circ} \mathrm{C}$ for $30 \mathrm{~s}$, followed by 40 cycles at $95^{\circ} \mathrm{C}$ for $5 \mathrm{~s}, 60^{\circ} \mathrm{C}$ for $30 \mathrm{~s}$, and $72^{\circ} \mathrm{C}$ for $30 \mathrm{~s}$.

\section{Data Analysis}

All values are expressed as mean \pm SD. Multiple sequence alignment of sNPFR sequences was performed with ClustalX and embellished by LaTEX TexShade (57). Data of ligand-receptor assays were analyzed using nonlinear curve fitting (GraphPad Prism 6.0) to obtain activation curves and $\mathrm{EC}_{50}$ values. The mRNA levels of $S p-V g$ and $S p-V g R$ gene were normalized against the internal control $\beta$-actin, and the relative expression was calculated using the $2^{-\Delta \Delta \mathrm{Ct}}$ method. Statistical significance was determined using one-way ANOVA followed by Duncan's multiple range tests. All statistical analyses were performed using IBM SPSS Statistics 20.0. Pictures were drawn by GraphPad Prism 6.0 and modified with Adobe Photoshop CS5.

\section{RESULTS}

\section{Cloning and Expression of Sp-sNPFR in HEK239T Cells}

Two partial sequences annotated as neuropeptide $\mathrm{Y}$ receptor type 2 (NPY2R) were mined from two transcriptome databases of S. paramamosain. The predicted Sp-sNPFR gene sequence (GenBank accession number: MH382826) encoding 458 amino acids was obtained when the two partial sequences were assembled. The protein sequence showed $60.1 \%$ identity to the mosquito, Aedes aegypti sNPF receptor, $61.1 \%$ identity to the African malaria mosquito, Anopheles gambiae sNPF receptor, $58.7 \%$ identity to $B$. mori sNPF receptor, $56.4 \%$ identity to
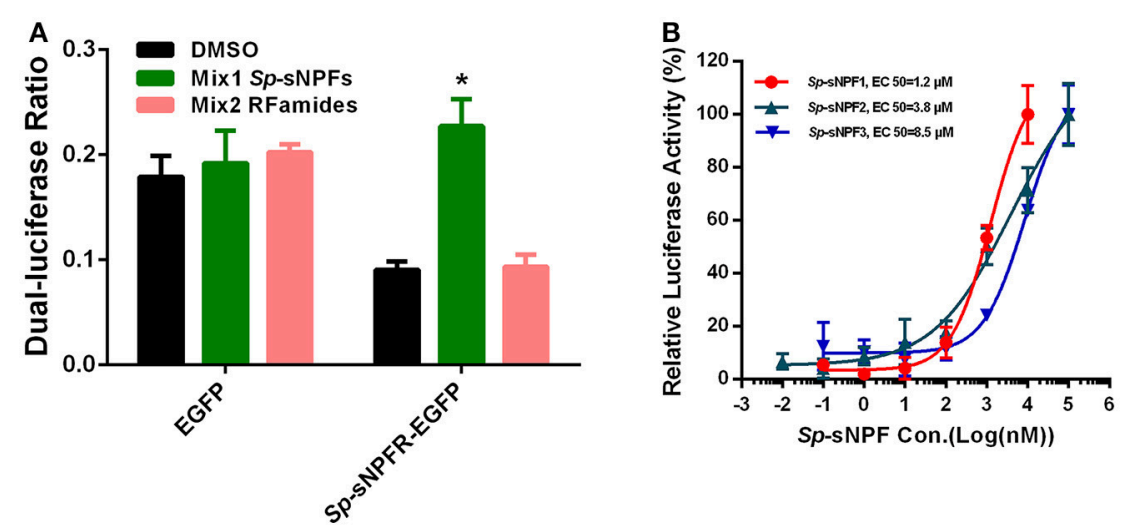

FIGURE 3 | Ligand-receptor activation of signaling. (A) Relative luciferase activity of Sp-sNPFR-EGFP expressing cells after exposure to two peptide mixutures with a fixed concentration of $1 \mu \mathrm{M}$ each peptide $\left({ }^{\star} P<0.05\right)$. (B) HEK293T transiently co-transfected with $S p$-sNPFR/pEGFP-N1, pCRE-luc, and pRL-TK were treated with different doses of Sp-sNPF1, Sp-sNPF2, and Sp-sNPF3 and the concentration of cAMP was determined. Values are plotted as mean \pm SD from three biological replicates. 
S. invicta sNPF receptor, $61.9 \%$ identity to the tsetse fly, Glossina morsitans morsitans sNPF receptor, $52.4 \%$ identity to the fruit fly, Drosophila melanogaster sNPF receptor, and $54.4 \%$ identity to the Desert Locust, Schistocerca gregaria sNPF receptor (Figure 1). Enhanced green fluorescent protein (EGFP) fused to the C-terminus of $S p$-sNPFR was transiently expressed in HEK293T. Confocal microscopy showed that Sp-sNPFREGFP mainly localized to the cell membrane as demonstrated (Figure 2).

\section{Activation of $S p$-sNPFR by $S p$-sNPFs}

We found that in cells transfected with $S p$-sNPFR and dualluciferase reporter, $S p$-sNPFR was exclusively activated by $S p$ sNPF peptides mixture, while all other FLPs with the RFamide C-terminus did not activate $S p$-sNPFR at $1 \mu \mathrm{M}$ concentration (Figure 3A). Furthermore, $S p$-sNPFR was found to be activated by all the three $S p$-sNPF peptides in a dose-dependent manner. The $\mathrm{EC}_{50}$ values were found to be $1.2,3.8$, and $8.5 \mu \mathrm{M}$ for $S p$-sNPF1, $S p$-sNPF2, and $S p$-sNPF3, respectively (Figure 3B).

\section{Localization of Sp-sNPF and Sp-sNPFR mRNA in the Ovary}

In the mud crab, ovary consists of oocytes and follicle layers surrounding the oocytes (Figure 4). Histological study showed that oocytes were larger in size than the follicle cells at previtellogenic stage (Figures 5A,B). In situ hybridization showed that the positive signals of $S p-s N P F$ mRNA were located on the follicle cells (Figure 5C) and $S p$-sNPFR was detected in both oocytes and follicle layer cells (Figure 5E). No signal was detected when the sense riboprobes of $S p-s N P F$ (Figure 5D) and $S p$ $s N P F R$ (Figure 5F) were used. Results of RT-PCR matched the findings of in situ hybridization (Figure 6).

\section{Oocytes Were Directly Activated by Sp-sNPFs}

Based on our finding that $S p-s N P F R$ mRNA was detected in denuded oocytes (Figure 6), we employed $\mathrm{Ca}^{2+}$ mobilization technology to investigate whether oocytes were activated by Sp-sNPFs. As shown in Figure 7, oocytes exhibited a dosedependent response in the intracellular $\mathrm{Ca}^{2+}$ mobilization when challenged with different concentrations of $S p$-sNPF peptides.

\section{Effect of Sp-sNPFs on Oocyte Maturation}

To explore the potential role of Sp-sNPF in oocyte maturation, denuded oocytes (GV stage) which were separated from the ovaries were chosen. As indicated in Figure 8A, denuded oocytes underwent GVBD fast and over 90\% oocytes exhibited GVBD after $15 \mathrm{~min}$ in the control group. However, the time of GVBD ratio was delayed to $30 \mathrm{~min}$ in oocytes treated with $5 \mu \mathrm{M} S p$-sNPF peptides (Figure 8A). Moreover, the GVBD ratio of oocytes was decreased in oocytes incubated with $S p$-sNPF1, Sp-sNPF2, and $S p$-sNPF3 for 5 min by 18,33 , and $21 \%$, respectively. GVBD ratio of oocytes was decreased by 14,12 , and $14 \%$, respectively, when $S p$-sNPF1, $S p$-sNPF2, and $S p$-sNPF3 were used for incubation at $15 \mathrm{~min}$ (Figure 8A). We also observed a higher level of cAMP in oocytes incubated with $5 \mu \mathrm{M} S p$-sNPF peptides (Figure 8B). This was in contrast to control oocytes where the cAMP level was reduced during the GVBD process (Figure $8 B$ ).

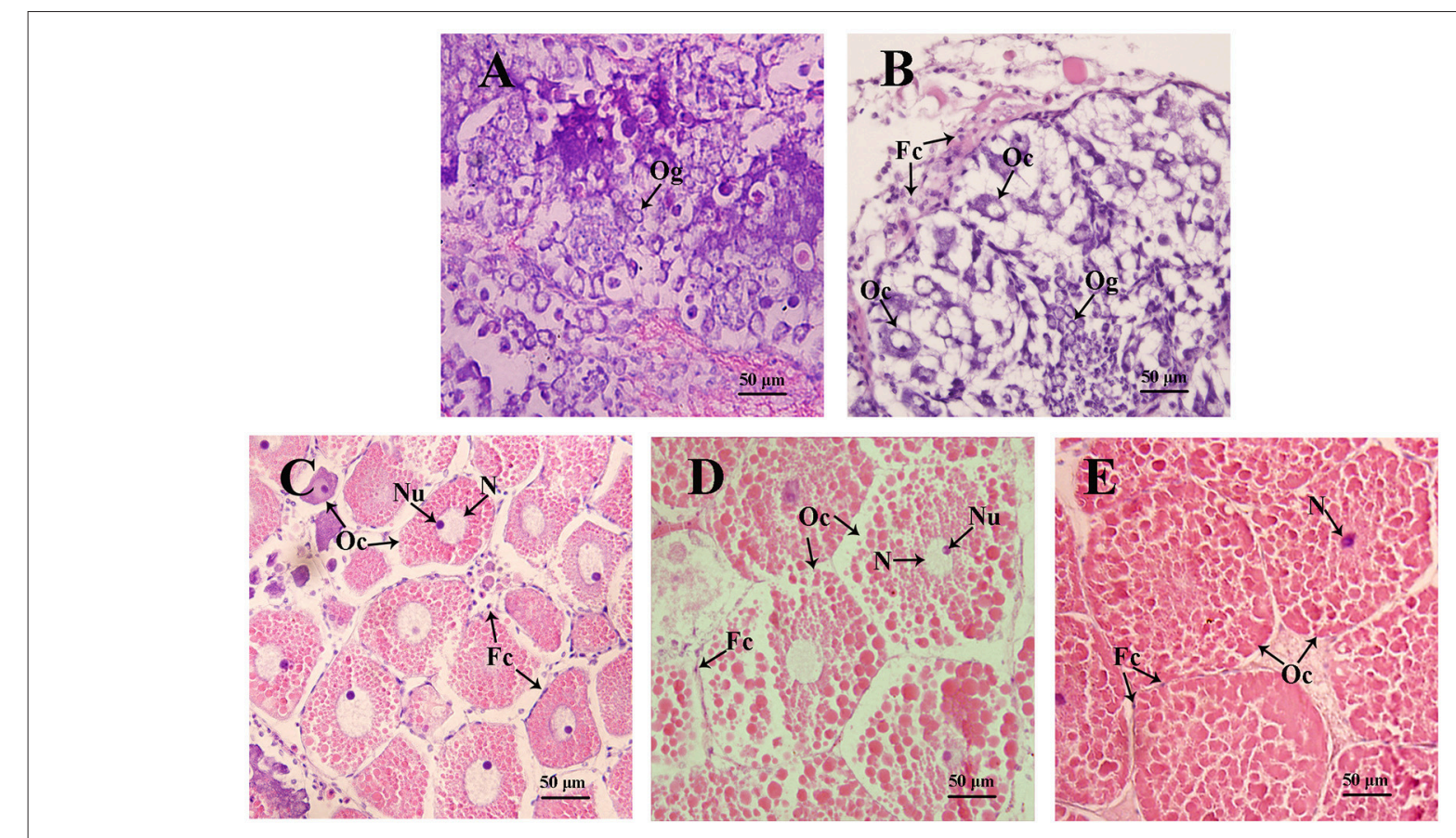

FIGURE 4 | Sections of ovaries from various stages of ovarian development in S. paramamosain. (A) undeveloped stage; (B) pre-vitellogenic stage; (C) early vitellogenic stage; (D) late vitellogenic stage; (E) mature stage. Fc, follicle cell; Oc, oocyte; Og, oogonium; N, nuclear; Nu, nucleolus. The arrows indicate different types of cells from various stages of ovaries. 


\section{Effect of Sp-sNPFs on Expression of $\mathrm{Sp}-\mathrm{Vg}$ and $S p-V g R$ in vivo}

Our previous study demonstrated that the expression of $S p-s N P F$ decreased continuously during vitellogenesis (44). In this study, we investigated the potential role of $\mathrm{NPF}$ in vitellogenesis by analyzing the effect of injected synthetic $S p$-sNPF peptides on the expression of $S p-V g$ and $S p-V g R$ in hepatopancreas and ovaries derived from pre-vitellogenic females. We found that injection of $S p$-sNPF1, $S p$-sNPF2, and $S p$-sNPF3 significantly inhibited $S p$ $V g$ expression in hepatopancreas by 78,59 , and $83 \%$, respectively. The expression level of $S p-V g R$ in ovaries was decreased by $74 \%$,

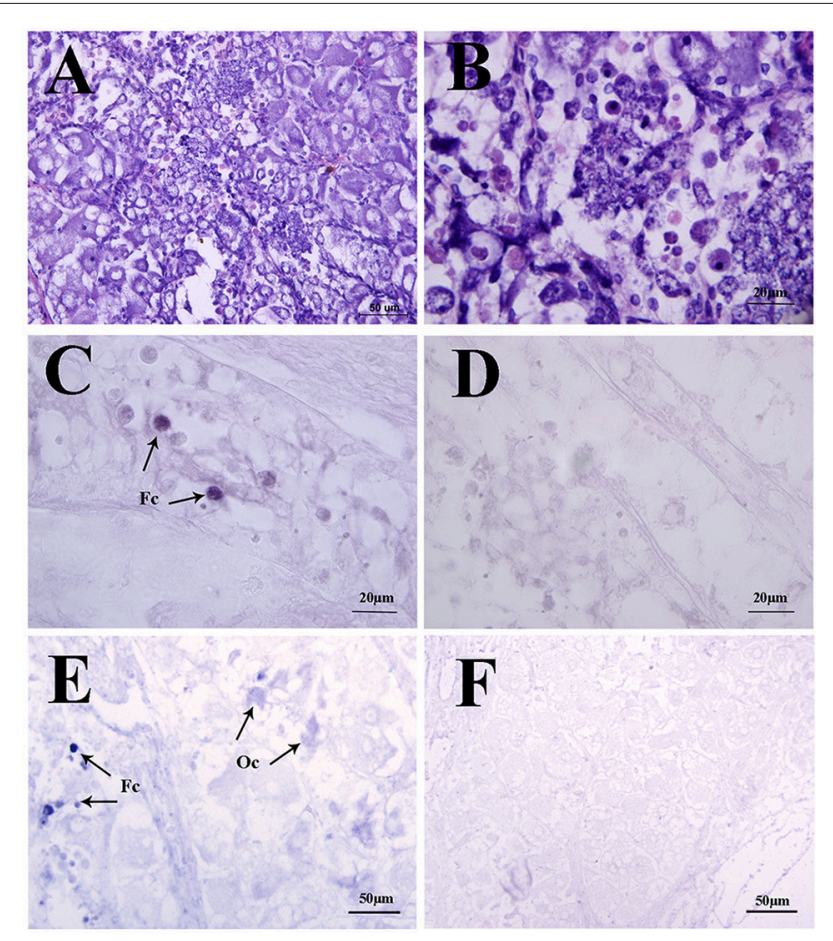

FIGURE 5 | Localization of Sp-sNPF and Sp-sNPFR mRNA by in situ hybridization in the mud crab ovaries at the pre-vitellogenic stage. (A, B) Hematoxylin and eosin (HE) staining in the ovaries. Arrows indicate the specific $S p$-sNPF (C) and Sp-sNPFR (E) mRNA signals with the antisense riboprobes in ovaries. Sense riboprobes of Sp-sNPF (D) and Sp-sNPFR (F) were used as the negative control. Fc, follicle cell; Oc, oocyte.
$56 \%$, and $68 \%$, in the presence of $S p$-sNPF1, $S p$-sNPF2, and Sp-sNPF3 respectively (Figure 9).

\section{DISCUSSION}

sNPFs have been identified from a broad range of arthropods (27). Since the discovery of the first sNPFR, a GPCR with structural similarity to NPY2R, in D. melanogaster (58), some sNPFRs have been identified in insects $(33,41,59-68)$. Although a large number of sNPFs have been characterized in different crustacean species (44-50), no sNPFR has been identified in crustaceans. In the present study, analyses of sequence similarity in transcriptome database revealed a candidate sNPFR annotated as a NPY-like receptor (NPY2R) in $S$. paramamosain. In addition, the ligand-receptor activation of signaling demonstrated that the candidate sNPFR was activated by three synthetic $S$. paramamosain sNPF peptides, $S p$-sNPF1, $S p$-sNPF2, and $S p$-sNPF3, in a dose-dependent manner, with $\mathrm{EC}_{50}$ of $1.2,3.8$, and $8.5 \mu \mathrm{M}$ respectively and which resulted in cAMP accumulation. All other tested peptides with the RFamide C-terminus did not elicit a cAMP response. Therefore, we designated the candidate sNPFR as the $S$. paramamosain sNPF receptor ( $S p$-sNPFR). To our knowledge, this receptor is the first crustacean $\mathrm{SNPF}$ receptor that has been characterized in this study.

To date, several insect sNPF receptors have been cloned and characterized $(33,41,59-68)$. Among these receptors, the sNPFRs from D. melanogaster $(67,68), A$. gambiae (60), B. mori (41, 61), S. gregaria (33), A. aegypti (62), S. invicta (63),

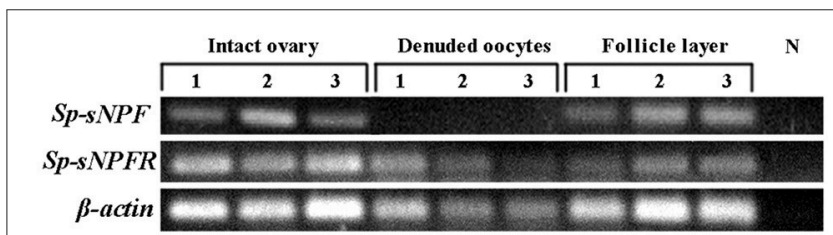

FIGURE 6 | Intraovarian distribution of Sp-sNPF and Sp-sNPFR mRNA in a full-grown ovary. RT-PCR detection of $S p$-sNPF and $S p$-sNPFR gene expression in different compartments of full-grown ovaries (follicle layer and denuded oocyte). Sp-sNPF was exclusively detected in follicle layer, whereas $S p$-sNPFR was expressed in both denuded oocytes and follicle layer. $\beta$-actin as the housekeeping gene.
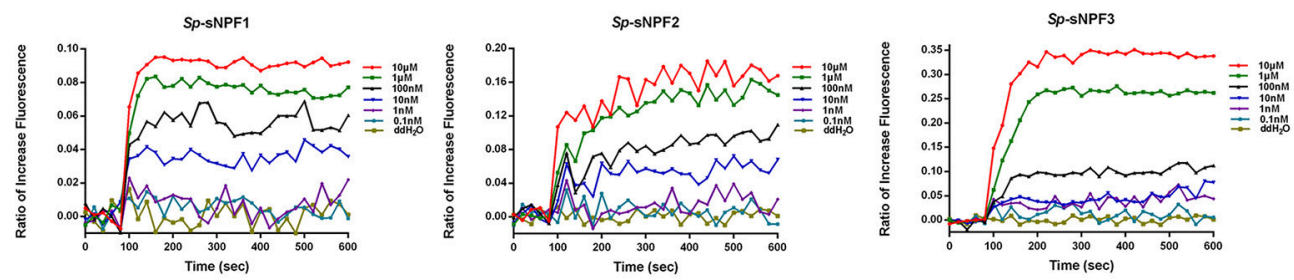

FIGURE 7 | Intracellular $\mathrm{Ca}^{2+}$ mobilization of oocytes was induced by Sp-sNPF peptides. Sp-sNPF peptides evoked intracellular Ca ${ }^{2+}$ flux in a ligand concentration-dependent manner in oocytes. All events were performed in at least three independent experiments. 

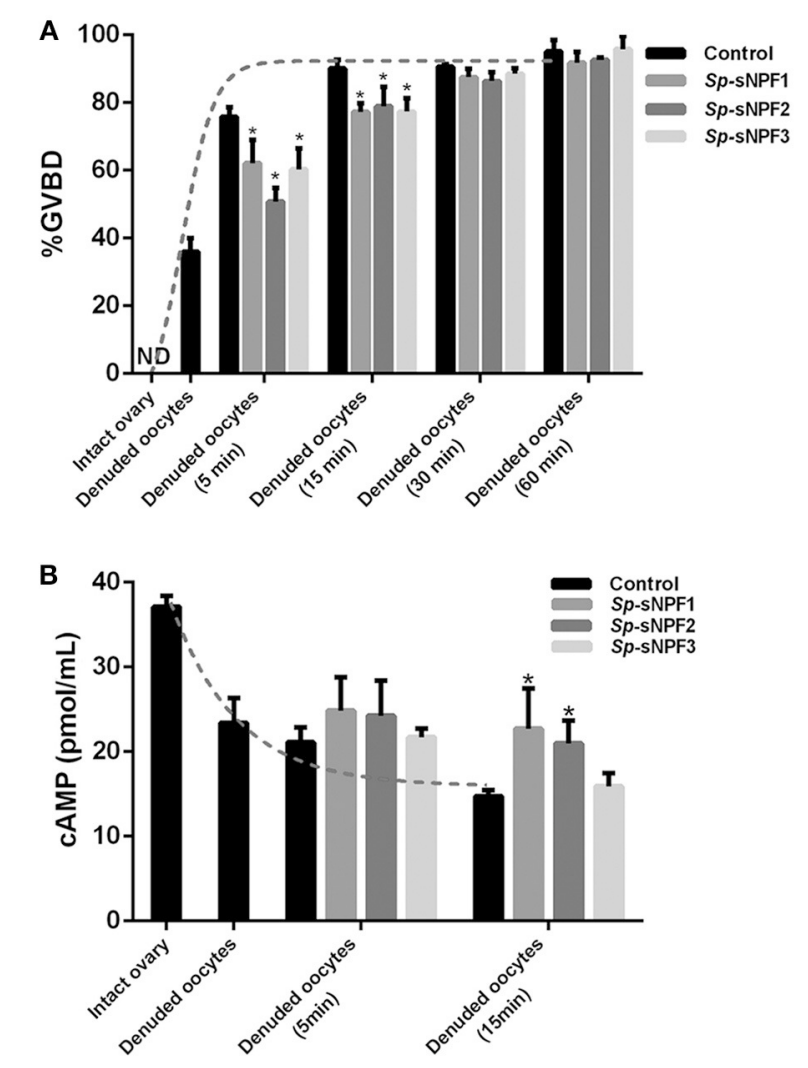

FIGURE 8 | Inverse effects of Sp-sNPF peptides on maturation of denuded oocytes. (A) Sp-sNPF peptides suppressed GVBD rate in denuded oocytes. Denuded oocytes were incubated in the presence or absence of Sp-sNPF peptides $(5 \mu \mathrm{M})$ for $0,5,15,30$, and 60 min before scoring GVBD oocytes. GVBD was inhibited by Sp-sNPF peptides at 5 and 15 min of incubation. The dotted line represents the GVBD rate trend of denuded oocytes which were isolated from an intact ovary in the control group. (B) CAMP accumulation was measured with ELISA. The dotted line represents the CAMP accumulation trend of denuded oocytes, which were isolated from intact ovary, in the control group. All values are presented as mean $\pm \mathrm{SD}(n=3)$ from three independent experiments ( $\left.{ }^{\star} P<0.05\right)$.

G. m. morsitans (64), and the oriental fruit fly, Bactrocera dorsalis (Hendel) (65) have been deorphanized by ligandreceptor activation of signaling in a heterologous cell expression system, with $\mathrm{EC}_{50}$ values in the nanomolar range. Compared to the high sensitivity of insect sNPFRs, Sp-sNPFR in our study had a relatively higher half-maximal effective concentration $\left(\mathrm{EC}_{50}\right)$ in the HEK293T expression system. Likewise, the intracellular $\mathrm{Ca}^{2+}$ concentration of $S$. paramamosain oocytes were mobilized by relatively high concentrations of synthetic $S p$-sNPF peptides in vitro. Nonetheless, our findings are similar to a study which showed that a short neuropeptide F-related receptor from the mollusk, Crassostrea gigas exhibited $\mathrm{EC}_{50}$ value in the micromolar range, similar to our results (69).

Studies in insect sNPFRs revealed that Si-sNPFR is localized in the ovary (43) suggesting that sNPF may directly act on ovary. As $S$. invicta sNPF was detected in the nervous system, authors speculated that SNPF may act as a neurohormone on the ovaries
(43). In our previous study (44), we found a higher level of $S p$ $s N P F$ transcript in the ovary of $S$. paramamosain suggesting that $S p$-sNPF may function as an autocrine/paracrine factor within the ovary.

Our results showed that $S p-s N P F$ mRNA was exclusively localized in the follicle cells, whereas $S p$-sNPFR was present in both follicle cells and oocytes. These results implied that $S p$-sNPF may bind $S p$-sNPFR via an autocrine/paracrine way. The localization of $S p$-sNPF and $S p$-sNPFR is consistent with the intraovarian expression pattern of $S$. paramamosain bone morphogenetic protein (Sp-BMP) and its receptors (54). BMP belongs to the transforming growth factor $\beta$ (TGF- $\beta$ ) superfamily, classical ovarian local autocrines/paracrines factors $(70,71)$. In vertebrates, BMPs and their receptors have a different localization, and are speculated to have an autocrine/paracrine regulatory mechanism in the ovary (72-75). The distribution of $S p$-sNPF and Sp-sNPFR suggested that there may be a similar autocrine/paracrine regulatory mechanism mediated by $S p$-sNPF in the ovary for follicle cells to signal the follicle cells/oocytes. Finally, the finding that the $S p$-sNPF peptides elicited a dramatic increase in intracellular $\mathrm{Ca}^{2+}$ is consistent with its proposed role as an intraovarian regulatory factor through an autocrine/paracrine regulatory mechanism.

When FG oocytes were separated from the follicle cells, they underwent spontaneous maturation with almost all oocytes exhibiting GVBD in $15 \mathrm{~min}$. Meanwhile, the cAMP level in the oocytes decreased significantly. In contrast, when Sp-sNPF peptides were added to the culture medium, GVBD rate of oocytes was significantly reduced, while the cAMP levels were partly reversed. This phenomenon is in agreement with the previous reports in zebrafish where removal of the follicle layers significantly increased in spontaneous maturation of the oocytes $(76,77)$. These findings suggest that surrounding follicle layer cells may play a similar role in both vertebrates and invertebrates in inhibiting oocyte maturation. The secretory factors that may be responsible for this inhibitory effect of follicle cells on oocyte maturation have not been fully explored. Estradiol $\left(\mathrm{E}_{2}\right)$ and Pituitary Adenylate Cyclase Activating Polypeptide (PACAP) were identified as two such factors where $\mathrm{E}_{2}$ partly inhibited the spontaneous maturation of the denuded oocytes via GPER, a membrane receptor located in the oocytes (76), and PACAP had a similar inhibitory effect on oocyte maturation (77). Sp-sNPF may be one such factor that suppresses oocyte maturation by binding to $S p$-sNPFR to promote cAMP accumulation. However, like $\mathrm{E}_{2}$ and PACAP, the inhibition of $S p$-sNPF was incomplete suggesting that other factors could be involved in this regulatory mechanism.

To provide further clues to elucidate the importance of $S p$-sNPF in S. paramamosain ovary, we performed in vivo experiments. In contrast to the previous reports in L. migratoria $(35,36)$, injection of $S p$-sNPF peptides significant suppressed the expression of $S p-V g R$ in the pre-vitellogenic stage ovary in our study. $\mathrm{VgR}$, located in the oocytes, has been regarded as a key receptor in the ovary which mediates the release of vitellogenin from hepatopancreas in crabs (78). Considering the correlation of $\mathrm{Vg} / \mathrm{VgR}$ system, we also examined the expression level of $S p$ $V g$ in hepatopancreas when the crabs were injected with $S p$-sNPF 

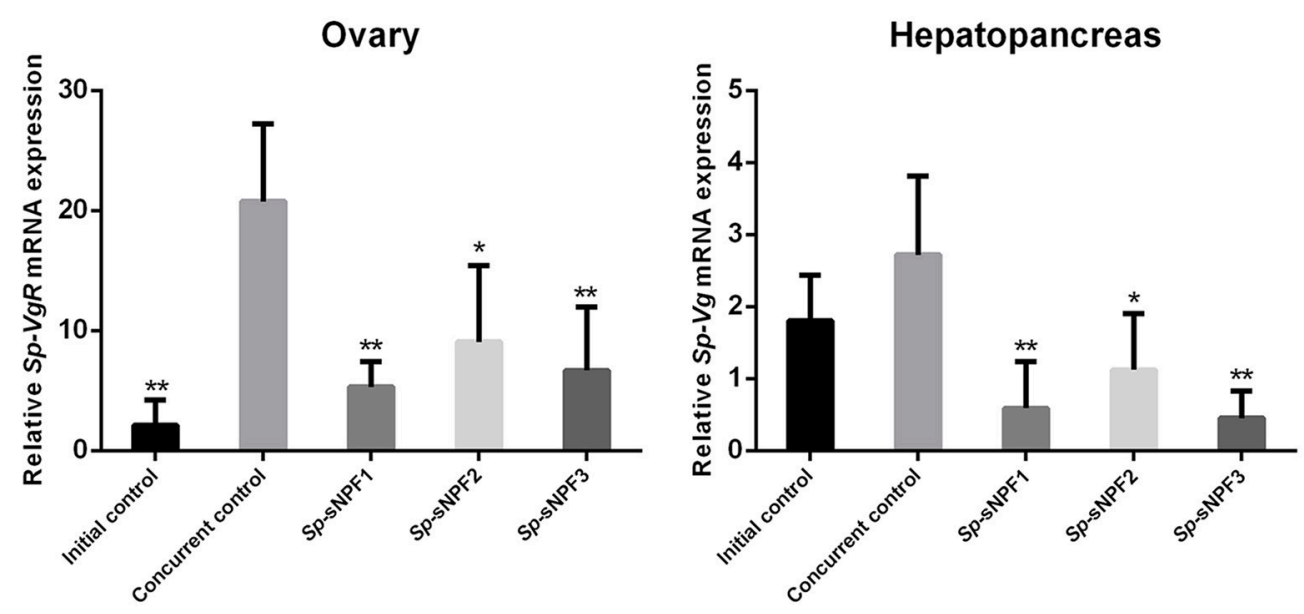

FIGURE 9 | Inhibitory effects of Sp-sNPF peptides on the expression of Sp-Vg and Sp-VgR in vivo. Hepatopancreas and ovaries were sampled at 10 days post-injection of $S p$-sNPF peptides for detecting the expression levels of $S p-V g$ and $S p-V g R$. The relative expression levels were normalized to $\beta$-actin. All data are presented as mean $\pm \mathrm{SD}(n=4)$ from a representative experiment. ${ }^{\star} P<0.05,{ }^{* \star} P<0.01 \mathrm{vs}$. concurrent control.

peptides. In agreement with the expression pattern of $S p-V g R$, $S p$-sNPF peptides exhibited a similar inhibitory effect on $S p-V g$ mRNA expression. The results suggest that $S p$-sNPF may be an inhibitor of vitellogenesis.

In summary, this study shows the $S$. paramamosain orphan receptor NPY2R is a receptor for the neuropeptide $S p$-sNPF ( $S p$ sNPFR). To our knowledge, this is the first sNPFR reported in crustaceans. Furthermore, the tissue and cellular localization of $S p$-sNPF/Sp-sNPFR and the signal transduction are consistent with its proposed function as an intraovarian regulatory factor inhibiting vitellogenesis and oocyte maturation through an autocrine/paracrine regulatory mechanism. This research provides a new insight into the SNPF functions in reproduction.

\section{REFERENCES}

1. Grimmelikhuijzen C, Leviev IK, Carstensen K. Peptides in the nervous systems of cnidarians: structure, function, and biosynthesis. Int Rev Cytol. (1996) 167:37-89. doi: 10.1016/S0074-7696(08)61345-5

2. Boonen K, Landuyt B, Baggerman G, Husson SJ, Huybrechts J, Schoofs L. Peptidomics: the integrated approach of MS, hyphenated techniques and bioinformatics for neuropeptide analysis. J Sep Sci. (2008) 31:427-45. doi: 10.1002/jssc. 200700450

3. Fricker LD. Neuropeptides and other bioactive peptides: from discovery to function. In: Devi L, Fricker LD, editors. Colloquium Series on Neuropeptides. California, CA: Morgan \& Claypool Publishers (2012). p. 1-122.

4. Hartenstein V. The neuroendocrine system of invertebrates: a developmental and evolutionary perspective. J Endocrinol. (2006) 190:555-70. doi: 10.1677/joe.1.06964

5. Seeburg PH, Mason AJ, Stewart TA, Nikolics K. The mammalian GnRH gene and its pivotal role in reproduction. In: Proceedings of the 1986 Laurentian Hormone Conference. Quebéc (1987). p. 69-98.

6. Millar RP, Newton CL. Current and future applications of GnRH, kisspeptin and neurokinin B analogues. Nat Rev Endocrinol. (2013) 9:451-66. doi: $10.1038 /$ nrendo.2013.120

7. Millar RP, Lu ZL, Pawson AJ, Flanagan CA, Morgan K, Maudsley SR. Gonadotropin-releasing hormone receptors.

\section{AUTHOR CONTRIBUTIONS}

CB: Conceptualization, data curation, software, methodology, writing-original draft, project administration; YY: Conceptualization, data curation, methodology, writingreview, and editing; HH: Supervision; HY: Conceptualization, supervision, funding acquisition.

\section{ACKNOWLEDGMENTS}

This study was supported by the National Natural Science Foundation of China (Nos. 41476119 and 31772827). We wish to thank Mr. Yuting Zhang for his technical support.

Endocr Rev. (2004) 25:235-75. doi: 10.1210/er.200

3-0002 releasing hormone in the ovary. Reprod Sci. (2007) 14:737-49. doi: 10.1177/1933719107310707

9. Cheung LW, Wong AS. Gonadotropin-releasing hormone: GnRH receptor signaling in extrapituitary tissues. FEBS J. (2008) 275:5479-95. doi: 10.1111/j.1742-4658.2008.06677.x

10. Shahed A, Young KA. Intraovarian expression of GnRH-1 and gonadotropin mRNA and protein levels in Siberian hamsters during the estrus cycle and photoperiod induced regression/recrudescence. Gen Comp Endocrinol. (2011) 170:356-64. doi: 10.1016/j.ygcen.2010.10.008

11. Hong IS, Cheung AP, Leung PC. Gonadotropin-releasing hormones I and II induce apoptosis in human granulosa cells. J Clin Endocrinol Metab. (2008) 93:3179-85. doi: 10.1210/jc.2008-0127

12. Leung PC, Cheng CK, Zhu XM. Multi-factorial role of GnRH-I and GnRH-II in the human ovary. Mol Cell Endocrinol. (2003) 202:145-53. doi: 10.1016/S0303-7207(03)00076-5

13. Ramakrishnappa N, Rajamahendran R, Lin YM, Leung PCK. GnRH in non-hypothalamic reproductive tissues. Anim Reprod Sci. (2005) 88:95-113. doi: 10.1016/j.anireprosci.2005.05.009

14. Bentley GE, Ubuka T, McGuire NL, Chowdhury VS, Morita Y, Yano $\mathrm{T}$, et al. Gonadotropin-inhibitory hormone and its receptor in the 
avian reproductive system. Gen Comp Endocrinol. (2008) 156:34-43. doi: 10.1016/j.ygcen.2007.10.003

15. Maddineni SR, Ocon-Grove OM, Krzysik-Walker SM, Hendricks GL, Ramachandran R. Gonadotropin-inhibitory hormone ( $\mathrm{GnIH}$ ) receptor gene is expressed in the chicken ovary: potential role of $\mathrm{GnIH}$ in follicular maturation. Reproduction (2008) 135:267-74. doi: 10.1530/REP-07-0369

16. Li X, Su J, Lei Z, Zhao Y, Jin M, Fang R, et al. Gonadotropin-inhibitory hormone $(\mathrm{GnIH})$ and its receptor in the female pig: cDNA cloning, expression in tissues and expression pattern in the reproductive axis during the estrous cycle. Peptides (2012) 36:176-85. doi: 10.1016/j.peptides.2012.05.008

17. Oishi H, Klausen C, Bentley GE, Osugi T, Tsutsui K, Gilks CB, et al. The human gonadotropin-inhibitory hormone ortholog RFamide-related peptide3 suppresses gonadotropin-induced progesterone production in human granulosa cells. Endocrinology (2012) 153:3435-45. doi: 10.1210/en.2012-1066

18. Ubuka T, Son YL, Bentley GE, Millar RP, Tsutsui K. Gonadotropin-inhibitory hormone (GnIH), GnIH receptor and cell signaling. Gen Comp Endocrinol. (2013) 190:10-7. doi: 10.1016/j.ygcen.2013.02.030

19. Gaytan F, Garcia-Galiano D, Dorfman MD, Manfredi-Lozano M, Castellano JM, Dissen, GA, et al. Kisspeptin receptor haplo-insufficiency causes premature ovarian failure despite preserved gonadotropin secretion. Endocrinology (2014) 155:3088-97. doi: 10.1210/en.2014-1110

20. Shahed A, Young KA. Differential ovarian expression of KiSS-1 and GPR54 during the estrous cycle and photoperiod induced recrudescence in Siberian hamsters (Phodopus sungorus). Mol Reprod Dev. (2009) 76:444-52. doi: $10.1002 / \mathrm{mrd} .20972$

21. Castellano JM, Gaytan M, Roa J, Vigo E, Navarro VM, Bellido C, et al. Expression of KiSS-1 in rat ovary: putative local regulator of ovulation? Endocrinology (2006) 147:4852-62. doi: 10.1210/en.2006-0117

22. Gaytán F, Gaytán M, Castellano JM, Romero M, Roa J, Aparicio B, et al. KiSS-1 in the mammalian ovary: distribution of kisspeptin in human and marmoset and alterations in KiSS-1 mRNA levels in a rat model of ovulatory dysfunction. Am J Physiol Endocrinol Metab. (2009) 296:E520-31. doi: 10.1152/ajpendo.90895.2008

23. Cielesh ME, McGrath BM, Scott CJ, Norman ST, Stephen CP. The localization of kisspeptin and kisspeptin receptor in the canine ovary during different stages of the reproductive cycle. Reprod Domest Anim. (2016) 52:24-8. doi: $10.1111 /$ rda. 12841

24. Törnell J, Carlsson B, Hillensjö T. Vasoactive intestinal peptide stimulates oocyte maturation, steroidogenesis, and cyclic adenosine 3,5'monophosphate production in isolated preovulatory rat follicles. Biol Reprod. (1988) 39:213-20. doi: 10.1095/biolreprod39.2.213

25. Canipari R, Di Paolo V, Barberi M, Cecconi S. PACAP in the reproductive system. In: Reglodi D, Tamas A, editors. Pituitary Adenylate Cyclase Activating Polypeptide-PACAP. Cham: Springer International Publishing (2016). p. 405-20.

26. Walker RJ, Papaioannou S, Holden-Dye L. A review of FMRFamideand RFamide-like peptides in Metazoa. Invert Neurosci. (2009) 9:111-53. doi: 10.1007/s10158-010-0097-7

27. Dick RN, Christian W. A comparative review of short and long neuropeptide F signaling in invertebrates: any similarities to vertebrate neuropeptide Y signaling. Peptides (2011) 32:1335. doi: 10.1016/j.peptides.2011.0 3.013

28. Veenstra JA, Lambrou G. Isolation of a novel RFamide peptide from the midgut of the American cockroach, Periplaneta americana. Biochem Biophys Res Commun. (1995) 213:519-24. doi: 10.1006/bbrc.1995.2162

29. Lee KS, You KH, Choo JK, Han YM, Yu K. Drosophila short neuropeptide F regulates food intake and body size. J Biol Chem. (2004) 279:50781-9. doi: 10.1074/jbc.M407842200

30. Lee KS, Kwon OY, Lee JH, Kwon K, Min KJ, Jung SA, et al. Drosophila short neuropeptide $\mathrm{F}$ signalling regulates growth by ERK-mediated insulin signalling. Nat Cell Biol. (2008) 10:468-75. doi: 10.1038/ncb1710

31. Lee KS, Hong SH, Kim AK, Ju SK, Kwon OY, Yu K. Processed short neuropeptide $\mathrm{F}$ peptides regulate growth through the ERK insulin pathway in Drosophila melanogaster. FEBS Lett. (2009) 583:2573-7. doi: 10.1016/j.febslet.2009.07.024

32. Dillen S, Verdonck R, Zels S, van Wielendaele P, vandenBroeck J. Identification of the short neuropeptide F precursor in the desert locust: evidence for an inhibitory role of sNPF in the control of feeding. Peptides (2014) 53:134-9. doi: 10.1016/j.peptides.2013.09.018

33. Dillen S, Zels S, Verlinden H, Spit J, van Wielendaele P, VandenBroeck J. Functional characterization of the short neuropeptide $\mathrm{F}$ receptor in the desert locust, Schistocerca gregaria. PLoS ONE (2013) 8:e53604. doi: 10.1371/journal.pone.0053604

34. Root CM, Ko KI, Jafari A, Wang JW. Presynaptic facilitation by neuropeptide signaling mediates odor-driven food search. Cell (2011) 145:133-44. doi: 10.1016/j.cell.2011.02.008

35. Cerstiaens ANJA, Benfekih L, Zouiten H, Verhaert P, De Loof A, Schoofs L. Led-NPF-1 stimulates ovarian development in locusts. Peptides (1999) 20:39-44. doi: 10.1016/S0196-9781(98)00152-1

36. Schoofs L, Clynen E, Cerstiaens A, Baggerman G, Wei Z, Vercammen T, et al. Newly discovered functions for some myotropic neuropeptides in locusts. Peptides (2001) 22:219-27. doi: 10.1016/S0196-9781(00)00385-5

37. De Loof A, Baggerman G, Breuer M, Claeys I, Cerstiaens A, Clynen E, et al. Gonadotropins in insects: an overview. Arch Insect Biochem Physiol. (2001) 47:129-38. doi: 10.1002/arch.1044

38. Kapan N, Lushchak V, Luo J, Nässel DR. Identified peptidergic neurons in the Drosophila brain regulate insulin-producing cells, stress responses and metabolism by coexpressed short neuropeptide F and corazonin. Cell Mol Life Sci. (2012) 69:4051-66. doi: 10.1007/s00018-012-1097-z

39. Badisco L, Van Wielendaele P, Broeck JV. Eat to reproduce: a key role for the insulin signaling pathway in adult insects. Front Physiol. (2013) 4:202. doi: 10.3389/fphys.2013.00202

40. Nässel DR, Broeck JV. Insulin/IGF signaling in Drosophila and other insects: factors that regulate production, release and post-release action of the insulin-like peptides. Cell Mol Life Sci. (2016) 73:271-90. doi: 10.1007/s00018-015-2063-3

41. Yamanaka N, Yamamoto S, Žitnan D, Watanabe K, Kawada T, Satake H, et al. Neuropeptide receptor transcriptome reveals unidentified neuroendocrine pathways. PLoS ONE (2008) 3:e3048. doi: 10.1371/journal.pone.0003048

42. Kaneko Y, Hiruma K. Short neuropeptide F (sNPF) is a stage-specific suppressor for juvenile hormone biosynthesis by corpora allata, and a critical factor for the initiation of insect metamorphosis. Dev Biol. (2014) 393:312-9. doi: 10.1016/j.ydbio.2014.07.014

43. Lu HL, Pietrantonio PV. Immunolocalization of the short neuropeptide F receptor in queen brains and ovaries of the red imported fire ant (Solenopsis invicta Buren). BMC Neurosci. (2011) 12:57. doi: 10.1186/1471-2202-12-57

44. Bao C, Yang Y, Huang H, Ye H. Neuropeptides in the cerebral ganglia of the mud crab, Scylla paramamosain: transcriptomic analysis and expression profiles during vitellogenesis. Sci Rep. (2015) 5:17055. doi: 10.1038/srep17055

45. Christie AE. Expansion of the Litopenaeus vannamei and Penaeus monodon peptidomes using transcriptome shotgun assembly sequence data. Gen Comp Endocrinol. (2014) 206:235-54. doi: 10.1016/j.ygcen.2014.04.015

46. Christie AE. Prediction of the peptidomes of Tigriopus californicus and Lepeophtheirus salmonis (Copepoda, Crustacea). Gen Comp Endocrinol. (2014) 201:87-106. doi: 10.1016/j.ygcen.2014.02.015

47. Christie AE. Prediction of Scylla olivacea (Crustacea; Brachyura) peptide hormones using publicly accessible transcriptome shotgun assembly (TSA) sequences. Gen Comp Endocrinol. (2016) 230:1-16. doi: 10.1016/j.ygcen.2016.03.008

48. Christie AE, Pascual MG. Peptidergic signaling in the crab Cancer borealis: Tapping the power of transcriptomics for neuropeptidome expansion. Gen Comp Endocrinol. (2016) 237:53-67. doi: 10.1016/j.ygcen.2016.08.002

49. Christie AE, Stemmler EA, Dickinson PS. Crustacean neuropeptides. Cell Mol Life Sci. (2010) 67:4135-69. doi: 10.1007/s00018-010-0482-8

50. Veenstra JA. Similarities between decapod and insect neuropeptidomes. Peer J. (2016) 4:e2043. doi: 10.7717/peerj.2043

51. Huang X, Ye H, Huang H, Yang Y, Gong J. An insulin-like androgenic gland hormone gene in the mud crab, Scylla paramamosain, extensively expressed and involved in the processes of growth and female reproduction. Gen Comp Endocrinol. (2014) 204:229-38. doi: 10.1016/j.ygcen.2014.06.002

52. Han K, Dai Y, Zou Z, Fu M, Wang Y, Zhang Z. Molecular characterization and expression profiles of $\mathrm{cdc} 2$ and cyclin $\mathrm{B}$ during oogenesis and spermatogenesis in green mud crab (Scylla paramamosain). Comp Biochem Physiol B Biochem Mol Biol. (2012) 163:292-302. doi: 10.1016/j.cbpb.2012.07.001 
53. Gong J, Ye H, Xie Y, Yang Y, Huang H. Li S, et al. Ecdysone receptor in the mud crab Scylla paramamosain: a possible role in promoting ovarian development. J Endocrinol. (2015) 224:273-87. doi: 10.1530/JOE-14-0526

54. Shu L, Yang Y, Huang H, Ye H. A bone morphogenetic protein ligand and receptors in mud crab: A potential role in the ovarian development. Mol Cell Endocrinol. (2016) 434:99-107. doi: 10.1016/j.mce.2016.06.023

55. Zeng $\mathrm{H}$, Bao $\mathrm{C}$, Huang $\mathrm{H}$, Ye $\mathrm{H}$, Li S. The mechanism of regulation of ovarian maturation by red pigment concentrating hormone in the mud crab Scylla paramamosain. Anim Reprod Sci. (2016) 164:152-61. doi: 10.1016/j.anireprosci.2015.11.025

56. Song YN, Shi LL, Liu ZQ, Qiu GF. Global analysis of the ovarian microRNA transcriptome: implication for miR-2 and miR-133 regulation of oocyte meiosis in the Chinese mitten crab, Eriocheir sinensis (Crustacea: Decapoda). BMC Genomics (2014) 15:47. doi: 10.1186/1471-2164-15-547

57. Beitz E. TeXshade: shading and labeling of multiple sequence alignments using LaTeX2e. Bioinformatics (2000) 16:135-9. doi: 10.1093/bioinformatics/16.2.135

58. Mertens I, Meeusen,T, Huybrechts R, De Loof A, Schoofs L. Characterization of the short neuropeptide F receptor from Drosophila melanogaster. Biochem Biophys Res Commun. (2002) 297:1140-8. doi: 10.1016/S0006-291X(02)02351-3

59. Feng G, Reale V, Chatwin H, Kennedy K, Venard R, Ericsson C, et al. Functional characterization of a neuropeptide F-like receptor from Drosophila melanogaster. Eur J Neurosci. (2003) 18:227-38. doi: 10.1046/j.1460-9568.2003.02719.x

60. Garczynski SF, Crim JW, Brown MR. Characterization of neuropeptide F and its receptor from the African malaria mosquito, Anopheles gambiae. Peptides (2005) 26:99-107. doi: 10.1016/j.peptides.2004.07.014

61. Ma Q, Cao Z, Yu Y, Yan L, Zhang W, Shi Y, et al. Bombyx neuropeptide $\mathrm{G}$ protein-coupled receptor $\mathrm{A} 7$ is the third cognate receptor for short neuropeptide F from silk worm. J Biol Chem. (2017) 292:20599-612. doi: 10.1074/jbc.M117.815191

62. Liesch J, Bellani LL, Vosshall LB. Functional and genetic characterization of neuropeptide Y-like receptors in Aedes aegypti. PLoS Negl Trop Dis. (2013) 7:e2486. doi: 10.1371/journal.pntd.0002486

63. Bajracharya $\mathrm{P}, \mathrm{Lu} \mathrm{HL}$, Pietrantonio PV. The red imported fire ant (Solenopsis invicta Buren) kept Y not F: predicted sNPY endogenous ligands deorphanize the short NPF (sNPF) receptor. PloS ONE (2014) 9:e109590. doi: 10.1371/journal.pone.0109590

64. Caers J, Peymen K, Van Hiel MB, Van Rompay L, Van Den Abbeele J, Schoofs $\mathrm{L}$, et al. Molecular characterization of a short neuropeptide F signaling system in the tsetse fly, Glossina morsitans morsitans. Gen Comp Endocrinol. (2016) 235:142-9. doi: 10.1016/j.ygcen.2016.06.005

65. Jiang HB, Gui SH, Xu L, Pei YX, Smagghe G, Wang JJ. The short neuropeptide F modulates olfactory sensitivity of Bactrocera dorsalis upon starvation. J Insect Physiol. (2017) 99:78-85. doi: 10.1016/j.jinsphys.2017. 03.012

66. Chen ME, Pietrantonio PV. The short neuropeptide F-like receptor from the red imported fire ant, Solenopsis invicta Buren (Hymenoptera: Formicidae). Arch Insect Biochem Physiol. (2006) 61:195-208. doi: 10.1002/arch.20103

67. Hauser F, Cazzamali G, Williamson M, Park Y, Li B, Tanaka Y, et al. A genome-wide inventory of neurohormone GPCRs in the red flour beetle Tribolium castaneum. Front Neuroendocrinol. (2008) 29:142-65. doi: 10.1016/j.yfrne.2007.10.003

68. Veenstra JA, Rombauts S, Grbić M. In silico cloning of genes encoding neuropeptides, neurohormones and their putative G-protein coupled receptors in a spider mite. Insect Biochem Mol Biol. (2012) 42:277-95. doi: 10.1016/j.ibmb.2011.12.009

69. Bigot L, Beets I, Dubos MP, Boudry P, Schoofs L, Favrel P. Functional characterization of a short neuropeptide F-related receptor in a lophotrochozoan, the mollusk Crassostrea gigas. J Exp Biol. (2014) 217:2974-82. doi: 10.1242/jeb.104067

70. Elvin JA, Clark AT, Wang P, Wolfman NM, Matzuk MM. Paracrine actions of growth differentiation factor-9 in the mammalian ovary. Mol Endocrinol. (1999) 13:1035-48. doi: 10.1210/mend.13.6.0310

71. Elvin JA, Yan C, Matzuk MM. Oocyte-expressed TGF- $\beta$ superfamily members in female fertility. Mol Cell Endocrinol. (2000) 159:1-5. doi: 10.1016/S0303-7207(99)00185-9

72. Clelland E, Peng C. Endocrine/paracrine control of zebrafish ovarian development. Mol Cell Endocrinol. (2009) 312:42-52. doi: 10.1016/j.mce.2009.04.009

73. Ge W. Intrafollicular paracrine communication in the zebrafish ovary: the state of the art of an emerging model for the study of vertebrate folliculogenesis. Mol Cell Endocrinol. (2005) 237:1-10. doi: 10.1016/j.mce.2005.03.012

74. Li CW, Ge W. Spatiotemporal expression of bone morphogenetic protein family ligands and receptors in the zebrafish ovary: a potential paracrinesignaling mechanism for oocyte-follicle cell communication. Bio Reprod. (2011) 85:977-86. doi: 10.1095/biolreprod.111.092239

75. Li CW, Zhou R, Ge W. Differential regulation of gonadotropin receptors by bone morphogenetic proteins in the zebrafish ovary. Gen Comp Endocrinol. (2012) 176:420-5. doi: 10.1016/j.ygcen.2011.12.032

76. Pang Y, Thomas P. Role of G protein-coupled estrogen receptor 1, GPER, in inhibition of oocyte maturation by endogenous estrogens in zebrafish. Dev Biol. (2010) 342:194-206. doi: 10.1016/j.ydbio.2010.03.027

77. Zhou R, Tsang AH, Lau SW, Ge W. Pituitary adenylate cyclase-activating polypeptide (PACAP) and its receptors in the zebrafish ovary: evidence for potentially dual roles of pacap in controlling final oocyte maturation. Bio Reprod. (2011) 85:615-25. doi: 10.1095/biolreprod.111.091884

78. Warrier S, Subramoniam T. Receptor mediated yolk protein uptake in the crab Scylla serrata: crustacean vitellogenin receptor recognizes related mammalian serum lipoproteins. Mol Reprod Dev. (2002) 61:536-48. doi: $10.1002 / \mathrm{mrd} .10106$

Conflict of Interest Statement: The authors declare that the research was conducted in the absence of any commercial or financial relationships that could be construed as a potential conflict of interest.

Copyright (C) 2018 Bao, Yang, Huang and Ye. This is an open-access article distributed under the terms of the Creative Commons Attribution License (CC BY). The use, distribution or reproduction in other forums is permitted, provided the original author(s) and the copyright owner(s) are credited and that the original publication in this journal is cited, in accordance with accepted academic practice. No use, distribution or reproduction is permitted which does not comply with these terms. 